\title{
Effects of Jerusalem Artichoke (Helianthus tuberosus L.) Extracts on Blood Glucose and Lipid Metabolism in STZ-induced Diabetic Rats
}

\author{
Hye-Jeong Kim ${ }^{1}$, Dong-Il Kim², and Jung-Min Yon ${ }^{3}$ \\ ${ }^{1}$ Department of Biomedical Laboratory Science, Kyungwoon University, Gumi 39160, Korea \\ ${ }^{2}$ Department of Health Care \& Biotechnology, Kyungwoon University, Gumi 39160, Korea \\ ${ }^{3}$ Research Institute of Veterinary Medicine, Chungbuk National University, Cheongju 28644, Korea
}

\section{돼지감자 추출액이 Streptozotocin으로 유발된 당뇨쥐에서 혈당 및 지질대사에 미치는 효과}

김예정 ${ }^{1}$, 김동일 $^{2}$, 연정민 $^{3}$

${ }^{1}$ 경운대학교 임상병리학과, ${ }^{2}$ 경운대학교 보건바이오학과, ${ }^{3}$ 충북대학교 동물의학연구소

\begin{abstract}
This study investigated the effect of Jerusalem artichoke (Helianthus tuberosus L.) extract on Blood Glucose and Lipid Metabolism in Streptozotocin (70 mg/kg B.W., i.p.)-induced Diabetic Rats. Sprague-Dawley male rats (200 220 g) were divided into normal control group (NC), diabetic control group (DC) and Jerusalem artichoke treated diabetic group (DJ). Diabetes was induced by single intraperitoneal injection of streptozotocin as a dose of $70 \mathrm{mg} / \mathrm{kg}$ body weight. Food $(p<0.001)$ and water $(p<0.05)$ intakes were higher in diabetic groups than the normal group. Body weight gain and food efficiency ratio were significantly lower in diabetic groups than normal group $(p<0.01)$. However, they were higher in the DJ group than in the DC group. The serum levels of AST and ALT were significantly lower in the DJ group than in the DC group $(p<0.05)$. The serum level of HDL-C was significantly higher in the DJ group than in the DC group $(p<0.001)$. The serum levels of Triglyceride ( $p<0.05)$, LDL-C $(p<0.001)$, and glucose $(p<0.001)$ were significantly lower in the D) group than in the DC group. At 3 and 4 weeks after the experiment, blood glucose level in the DJ group was significantly lower than the DC group $(p<0.05)$. In conclusion, these results indicated that Jerusalem artichoke can prevent or retard the development of diabetic complications via its beneficial effects for alleviating the hyperglycemia and improved lipid metabolism.
\end{abstract}

Keywords: Blood glucose, Jerusalem artichoke, Lipid, Streptozotocin

This is an Open Access article distributed under the terms of the Creative Commons Attribution Non-Commercial License (http://creativecommons.org/licenses/by-nc/4.0) which permits unrestricted non-commercial use, distribution, and reproduction in any medium, provided the original work is properly cited.

Copyright @ 2015 The Korean Society for Clinical Laboratory Science. All rights reserved.
Corresponding author: Hye-Jeong Kim Department of Biomedical Laboratory Science, Kyungwoon University, Gumi 39160, Korea Tel: 82-54-479-1283 E-mail: hjkim11@ikw.ac.kr

Received: October 22, 2015 Revised $1^{\text {st: }}$ November 21, 2015 Revised $2^{\text {nd }}:$ December 1, 2015 Accepted: December 1, 2015

\section{서 론}

질병관리본부와 보건복지부에서 우리나라 30 세 이상 성인을 대 상으로 시행한 2010 년 국민건강영양조사 자료에 의하면 성인 10 명 중 1 명이 당뇨병환자(당뇨병 유병률 $10.1 \%$, 남성 $11.3 \%$, 여성
$9.0 \%$ )이며 성인 10 명 중 3 명이 당뇨병환자 및 잠재적당뇨병으로 발표하였다. 대한당뇨병학회에서는 2050년도에는 당뇨병환자수 가 약 600만명으로 추정하고 있다고 발표하였다(Ministry of Health and Welfare, 2010; KDA 와 KCDC, 2012).

당뇨병은 급성 감염성 질환에서 만성 퇴행성 질환으로 변화하고 
있으며 인슐린 부족이나 인슐린에 대한 저항성의 증가로 인해 발병 되는 당뇨병의 경우 오래 지속되어 여러 합병증을 유발한다. 그 종 류로는 대 혈관 합병증인 동맥경화, 고혈압, 심근경색등과 미세혈 관 합병증인 신증, 신경변증, 망막증 등이 있다(West 등, 1983). 대 혈관 합병증의 주요 원인은 혈당 농도의 상승과 함께 지질 대사의 비정상성을 들 수 있으며, 우리나라 당뇨병환자의 $3 / 4$ 이 비만이거 나 과체중으로 혈중 중성지방의 증가, 고밀도지단백-콜레스테롤 (high density lipoprotein cholesterol, HDL-cholesterol)의 감 소, 저밀도지단백-콜레스테롤(low density lipoprotein cholesterol, LDL-cholesterol)롤의 증가 등의 지질대사 이상을 들 수 있다 (Treayway 등, 2001; $\mathrm{KDA}$ 와 $\mathrm{KCDC}, 2012$ ).

돼지감자(Helianthus tuberosus L.)는 국화과 해바라기속 다년 생 식물로서 주성분은 inulin이며, 돼지감자 건물(dry weight)의 약 $75 \%$ 를 차지한다. 이는 인간의 위액과 소화효소에 의해서 분해 되지 않고 장내 미생물에 의하여 발효되어 장내환경 개선 및 배변 기능 촉진에 효과가 있다. 열량이 낮아 $(1.0 \sim 1.5 \mathrm{kcal} / \mathrm{g}$ ) 비만개선 효과, 중성지질의 감소효과, 대장암 발생억제 등의 효과가 있다고 보고되고 있다(Kleessen 등, 2007; Kim 등, 2010). 돼지감자는 칼 로리가 낮고 미네랄과 비타민이 풍부하며, 주성분인 과당(fructose) 의 중합체인 이눌린(inulin)은 소화효소에 의해 분해되지 않는 식 이섬유소로(Bach 등, 2012), 이러한 특성 때문에 혈당량을 급격하 게 상승시키지 않아 당뇨병환자의 식이로 적합하며 최근에는 암을 예방하는 등 건강 증진효과도 보고되고 있다(Baltacioglu과 Esin, 2012).

현대과학의 큰 발전에도 불구하고 당뇨병의 발병률은 증가하고 있으며 그 예방과 치료에 대한 관심이 집중되고 있다. 이러한 당뇨 병의 치료 및 합병증 예방을 위해 최근에는 장기간 복용에도 부작 용이 없는 천연 식물 및 천연 기능성식품을 이용한 연구가 활발히 진행되고 있다(Park 등, 2015; Park과 Han, 2015). 그중 식이섬유 가 풍부한 천연식물은 혈당과 혈중 지질을 낮추어 비만과 당뇨환자 에게 주목받고 있다(Roberfroid, 1999; Kim 등, 2014). 본 연구에 서는 식이섬유가풍부한 돼지감자추출물을 이용하여 Streptozotocin (STZ)로 유발된 I형 당뇨 모델에서 혈당 및 혈중지질대사 개선효과 를 살펴보고 당뇨병 예방 기능성식품 소재 개발을 위한 기초 자료 가 되고자 한다.

\section{재료 및 방법}

\section{1. 실험동물}

실험동물은 (주오리엔트바이오의 Sprague-Dawley 랫드(200 220 g) 수컷(Orient Bio Co., Gyeonggi, Korea)을 분양 받아 1주
일 적응 시킨 후 난괴법에 의해 3 군(정상군 $\mathrm{NC}$, 당뇨대조군 $\mathrm{DC}$, 당 뇨돼지감자군 DJ)으로 나누어 각 군당 7마리씩 4주간 사육하여 실 험하였다. 혈당은 매주 14:00 15:00시에 측정하였으며, 실험 추 출액은 $4 \mathrm{~mL} / \mathrm{kg}$ body weight/day 용량으로 주 6일, 4주간 경구투 여하였다. 사료섭취량과 물은 매일, 체중은 주 1회 측정하여 식이 효율을 분석하였다. 식이효율(Food efficiency ratio)=(몸무게증 가량/식이량 $) \times 100$. 모든 실험은 충북대학교 동물실험윤리위원회 규정에 입각하여 실시하였다(Chungbuk National University Animal Care Committee, according to NIH \#86-23, 2014).

\section{2. 당뇨 유발}

인슐린 의존성 당뇨병과 유사한 실험동물을 만들기 위하여 Streptozotocin (STZ; Sigma Co., Louis, MO, USA)을 0.4 M citrate buffer 용액에 용해시켜 $70 \mathrm{mg} / \mathrm{kg}$ body weight 용량(0.5 $\mathrm{mL} / 100 \mathrm{~g}$ body weight)으로 복강 내 주사하였다. 당뇨 유발 확인 은 STZ 주사 72 시간 후 미정맥에서 채혈하여 혈당량이 $300 \mathrm{mg} / \mathrm{dL}$ 이상이면 당뇨병이 유발된 것으로 간주하였다.

\section{3. 돼지감자의 제조}

돼지감자 추출액은 (주홍천마의 돼지감자 진액당(Hongcheonma Co., Gyeongbuk, Korea) 을 사용하였다. 제품의 제조법은 1주일 이상 숙성된 돼지감자를 사용하여 돼지감자를 분쇄기분쇄기 (Daewoo Co., Gyeongggi, Korea)로 마쇄한 후 중탕기(Daewoo Co., Seoul, Korea)에 넣고 $70 \sim 80^{\circ} \mathrm{C}$ 45시간 열을 가하고 얻어진 시료를 본 실험에 사용하였다.

\section{4. 혈당 측정}

실험기간 동안 매주 동일시간에 미정맥에서 혈액(전혈)을 채취 하여 간이혈당계 Gluco Navi NFC (SD Biosensor Co., Suwon, Korea)를 사용하여 Glucose Dehydrogenase Biosensor 방식으 로 혈당을 측정하였다.

\section{5. 실험동물 처치 및 생화학적 검사}

실험사육 4 주 후 랫드를 12 시간 동안 절식 시킨 후 28 일째 날에 ether 마취 하에 복부대동맥에서 혈액을 채취하여 혈청을 분리한 후 aspartate aminotransferase (AST), alanine aminotransferase (ALT), alkaline phosphatase (ALP), triglyceride (TG), cholesterol, high density lipoprotein-cholesterol (HDL-C), low density lipoproteinL-cholesterol (LDL-C), glucose 농도는 Cobas-C311 자동생화학분석기와 관련 시약(Roche Co., San Francisco, USA) 을 사용하여 면역화학적 방법으로 측정하였다. 


\section{6. 자료 분석}

실험결과는 평균과 표준편차로 나타내었으며, SPSSWIN version 18.0 (SPSS Inc., Chicago, IL. USA) 통계프로그램을 이용 하여 one-way ANOVA 분석 후 $p<0.05$ 수준에서 Duncan's multiple rang test에 의해 검정하였다.

\section{결 과}

\section{1. 물, 식이 섭취량, 체중 및 식이효율}

실험식이로 4 주간 사육한 실험동물의 음수량은 당뇨군이 $156.38 \pm 22.16$ 으로 정상군 $37.79 \pm 3.84$ 에 비해 약 3 배 유의하게 높게 나타났다. 그러나 식이섭취량은 당뇨군이 정상군에 비해 각 $3.3 \%(\mathrm{DC}), 14.4 \%(\mathrm{DJ})$ 증가한 것으로 나타났다. 체중증가는 당뇨 군은 정상군에 비해 각 $79.6 \%(\mathrm{DC}), 59.4 \%(\mathrm{DJ})$ 유의하게 낮은 수 치를 보여 당뇨로 인한 체중감소를 나타내었다. 그러나 당뇨돼지감 자군은 $45.71 \pm 48.5$ 로 당뇨대조군 $23.00 \pm 34.22$ 에 비해 $98.7 \%$ 높은 수치를 나타내었고 식이효율도 유사한 양상을 나타내었다 (Table 1).

\section{2. 간 기능 검사}

실험동물의 혈청을 이용한 간기능 검사의 AST는 정상군 $(\mathrm{NC})$ 에 비해 당뇨대조군(DC)이 $19.3 \%$ 유의하게 증가하였으며 $(p<0.05)$, ALT는 정상군에 비해 당뇨대조군이 $41.0 \%$ 유의하게 증가하였다 $(p<0.05)$. 그러나 당뇨대조군( $\mathrm{DC})$ 에 비해 당뇨돼지감자군(DJ)은 $\mathrm{AST}$ 는 $14.3 \%$ 유의한 감소를 보였으며, ALT는 $27.3 \%$ 유의한 감소

Table 1. Water intake, food intake, body weight gain and fool efficiency ratio of normal and diabetic rats fed the experimental extract for 4 weeks

\begin{tabular}{cccc}
\hline \multirow{2}{*}{ Items } & NC & \multicolumn{2}{c}{ Diabetic groups } \\
\cline { 3 - 4 } & & DC & DJ \\
\hline $\begin{array}{c}\text { Water intake } \\
(\mathrm{mL} / \text { day) }\end{array}$ & $37.79 \pm 3.84^{\dagger, \mathrm{a}}$ & $156.38 \pm 22.16^{\mathrm{b}}$ & $147.75 \pm 20.12^{\mathrm{b}}$ \\
$\begin{array}{c}\text { Food intake } \\
(\mathrm{g} / \text { day) }\end{array}$ & $26.18 \pm 3.20^{\mathrm{a}}$ & $27.05 \pm 2.96^{\mathrm{a}, \mathrm{b}}$ & $29.95 \pm 1.92^{\mathrm{b}}$ \\
$\begin{array}{c}\text { Body weight } \\
\text { gain (g) }\end{array}$ & $112.57 \pm 15.03^{\mathrm{b}}$ & $23.00 \pm 34.22^{\mathrm{a}}$ & $45.71 \pm 48.58^{\mathrm{a}}$ \\
$\begin{array}{c}\text { Food } \\
\text { efficiency } \\
\text { ratio* }(\%)\end{array}$ & $4.33 \pm 0.56^{\mathrm{b}}$ & $0.98 \pm 1.56^{\mathrm{a}}$ & $1.51 \pm 1.60^{\mathrm{a}}$ \\
\hline
\end{tabular}

Abbreviation: NC, Normal Control; DC, Diabetic Control; DJ, Diabetic Jerusalem artichoke.

${ }^{*}$ Food efficiency ratio: body weight gain/food intake, ${ }^{\dagger}$ Values are mean \pm SD of 7 rats.

Different alphabets in each values show statistically significantly difference $(p<0.05)$ by Duncan's multiple range test.
를 나타내었다. ALP는 당뇨대조군에 비해 당뇨돼지감자군은 $15.6 \%$ 감소를 나타내었다(Table 2).

\section{3. 혈청 $\mathrm{TG}, \mathrm{CHOL}, \mathrm{HDL}-\mathrm{C}, \mathrm{LDL}-\mathrm{C}$ 및 glucose 검사}

실험동물의 혈청을 이용한 지방대사 $\mathrm{TG}$ 의 농도는 정상군 $(\mathrm{NC})$ 에 비해 당뇨대조군(DC)이 $41.0 \%$ 증가하였으나 당뇨대조군(DC)에 비 해 당뇨돼지감자군(DJ)은 $25.4 \%$ 유의한 감소를 보였다 $(p<0.05)$. $\mathrm{HDL}-\mathrm{C}$ 농도는 정상군에 비해 당뇨대조군이 $30.5 \%$ 유의하게 감소 하였으나 당뇨대조군에 비해 당뇨돼지감자군은 $31.8 \%$ 유의한 증 가를 보였다 $(p<0.05) . \mathrm{LDL}-\mathrm{C}$ 는 정상군에 비해 당뇨대조군이 $177.8 \%$ 유의하게 증가하였으나 당뇨대조군에 비해 당뇨돼지감자 군은 $56.6 \%$ 유의한 감소를 보였다 $(p<0.05)$. 4주간 사육한 실험동 물의 혈청 glucose는 정상군에 비해 당뇨대조군이 $57.9 \%$ 유의하 게 증가하였으나 당뇨대조군에 비해 당뇨돼지감자군에서 33.0\% 유의한 감소를 나타내었다(Table 3).

\section{4. 혈중 포도당 변화}

실험동물 혈중포도당 농도 변화를 알아본 결과, 실험시작 혈중 포도 당 농도는 정상군 $147.00 \pm 7.96$ 에 비하여 당뇨군은 $428.57 \pm 127.88$

Table 2. AST, ALT and ALP levels of normal and diabetic rats fed the experimental extract for 4 weeks

\begin{tabular}{cccc}
\hline \multirow{2}{*}{ Items } & NC & \multicolumn{2}{c}{ Diabetic groups } \\
\cline { 3 - 4 } & & DC & DJ \\
\hline AST $(\mu / L)$ & $166.14 \pm 10.76^{\mathrm{a}}$ & $198.17 \pm 23.46^{\mathrm{b}}$ & $169.83 \pm 11.86^{\mathrm{a}}$ \\
ALT $(\mu / \mathrm{L})$ & $41.14 \pm 4.49^{\mathrm{a}}$ & $58.00 \pm 15.30^{\mathrm{b}}$ & $42.17 \pm 3.60^{\mathrm{a}}$ \\
ALP $(\mu / \mathrm{L})$ & $256.71 \pm 41.10$ & $307.33 \pm 62.32$ & $259.33 \pm 69.08$ \\
\hline
\end{tabular}

Abbreviation: AST, aspartate aminotransferase; ALT, alanine aminotransferase; ALP, alkaline phosphatase.

Different alphabets in each values show statistically significantly difference $(p<0.05)$ by Duncan's multiple range test.

Table 3. Serum TG, CHOL, HDL-C, LDL-C and glucose levels of normal and diabetic rats fed the experimental extract for 4 weeks

\begin{tabular}{lccc}
\hline \multirow{2}{*}{ Items } & \multirow{2}{*}{$\mathrm{NC}$} & \multicolumn{2}{c}{ Diabetic groups } \\
\cline { 3 - 4 } & & $\mathrm{DC}$ & $\mathrm{DJ}$ \\
\hline $\mathrm{TG}(\mathrm{mg} / \mathrm{dL})$ & $32.50 \pm 10.37^{\mathrm{a}}$ & $45.83 \pm 8.54^{\mathrm{b}}$ & $34.17 \pm 7.68^{\mathrm{a}}$ \\
$\mathrm{CHOL}(\mathrm{mg} / \mathrm{dL})$ & $37.43 \pm 6.50$ & $36.33 \pm 4.08$ & $35.67 \pm 5.05$ \\
$\mathrm{HDL}-\mathrm{C}(\mathrm{mg} / \mathrm{dL})$ & $134.29 \pm 3.35^{\mathrm{c}}$ & $93.33 \pm 3.44^{\mathrm{a}}$ & $123.00 \pm 4.69^{\mathrm{b}}$ \\
$\mathrm{LDL}-\mathrm{C}(\mathrm{mg} / \mathrm{dL})$ & $50.57 \pm 2.64^{\mathrm{a}}$ & $140.50 \pm 3.27^{\mathrm{c}}$ & $61.00 \pm 2.00^{\mathrm{b}}$ \\
Glucose & $80.26 \pm 1.00^{\mathrm{a}}$ & $126.75 \pm 7.33^{\mathrm{b}}$ & $84.97 \pm 1.09^{\mathrm{a}}$ \\
$\quad(\mathrm{mg} / \mathrm{dL})$ & & &
\end{tabular}

Abbreviation: TG, triglyceride; $\mathrm{CHOL}$, cholesterol; $\mathrm{HDL}-\mathrm{C}$, high density lipoprotein-cholesterol; LDL-C, low density lipoproteinL-cholesterol. Different alphabets in each values show statistically significantly difference $(p<0.05)$ by Duncan's multiple range test. 


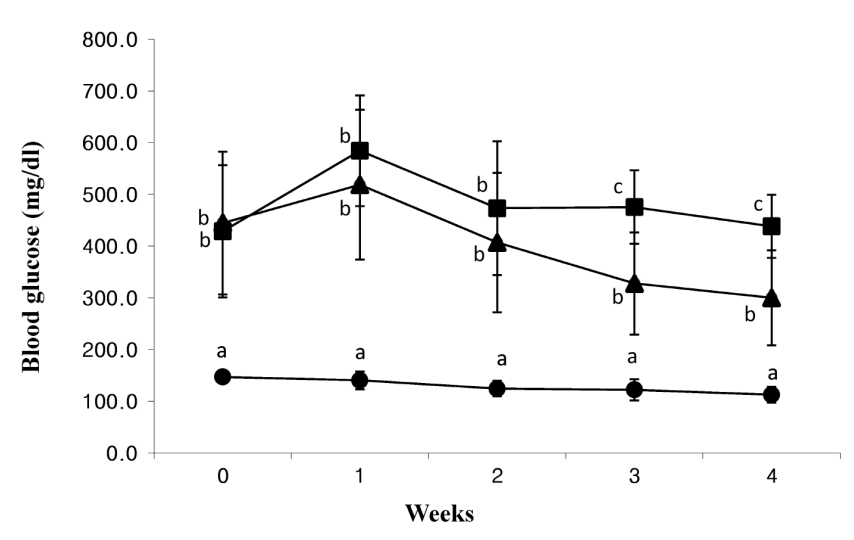

Fig. 1. Changes in blood glucose levels of normal and diabetic rats fed the experimental extract for 4 weeks. Different alphabets in each values show statistically significantly difference $(p<0.05)$ by Duncan's multiple range test. $\mathrm{O}$, NC $\mathbf{\square}, \mathrm{DC} ; \boldsymbol{\Delta}, \mathrm{DJ}$.

(DC), $444.67 \pm 138.24$ (DJ)로 혈당이 3 4배 유의하게 높았다 $(p<0.05)$. 당뇨군은 1주째 급격히 증가 후 2주째 당뇨대조군은 473.29 129.29 로 서서히 감소하는 현상을 보였으나 당뇨돼지감 자군은 $406.83 \pm 134.98$ 로 빠르게 감소하는 변화를 나타내었다. 당뇨 유발 후 3주째는 당뇨대조군 475.50 171.09 에 비하여 당뇨 돼지감자군은 $327.83 \pm 98.83$ 로 $31.0 \%$ 유의하게 감소하였고 $(p<0.05), 4$ 주째는 당뇨대조군 438.33 01.13 에 비하여 당뇨돼 지감자군은 $300.00 \pm 91.87$ 로 $31.6 \%$ 유의하게 감소하는 현상을 보였다(Fig. 1).

\section{고 찰}

당뇨병은 암 및 순환기계 질환과 함께 극복되지 않은 3대 난치병 질병 중 하나로 지목되면서 당뇨병에 대한 예방과 치료에 대한 관 심이 집중되고 있다(Choi, 2011; Lee 등, 2013). 하지만 약물치료 에 한계가 있어 장기간 복용에도 안정성이 보장된 천연추출물을 이 용한 연구가 활발히 진행되고 있다(Park 등, 2015; Park과 Han, 2015). 인슐린 의존성 당뇨병의 연구는 당뇨유발 약물로 알려진 streptozotocin (STZ)을 투여한 실험동물에서 이루어지고 있다 (Connelly 등, 2007). 이 약물은 주로 췌장 Langerhans' islet의 $\beta$-cell 만을 선택적으로 산화시켜 파괴하여 인슐린 분비를 감소시 킴으로 당뇨병이 유발 되는 것으로 알려져 있다(Dunn과 McLetchie, 1943). 본 연구에서는 STZ로 유발된 I형 당뇨 모델에서 식이섬유가 풍부한 돼지감자 추출물의 경구투여가 혈당 및 혈중지질대사 개선 효과가 있는지 알아보고자 하였다.

당뇨가 유발된 쥐는 정상쥐에 비하여 5 8배의 높은 음수량을 보고하고 있으며(Yoon과 Son, 2009), 재흡수되지 못하고 소변으 로 배출되는 포도당은 체내수분을 같이 끌고 체외로 배출되기 때문
에 소변 량이 증가하며 따라서 체내수분의 손실도 많아지고 음수량 도 증가하게 된다(Lee와Jun, 2004). 본 연구에서도 음수량은 당뇨 군이 정상군에 비해 약 3 배 현저하게 높게 나타났다. 그러나 식이섭 취량은 당뇨군이 정상군에 비해 다소 증가한 것으로 나타났다. 췌 장의 $\beta$-cell이 파괴되어 당 대사의 불균형을 초래한 당뇨쥐는 식이 효율이 떨어지고 체중이 감소하는 것으로 보고되고 있다(Jekal 등, 2008). 본 연구에서 체중은 당뇨군이 정상군에 비해 체중감소를 나 타내었으나 당뇨돼지감자군은 당뇨대조군에 비해 체중증가를 나 타내었으며 식이효율도 다소 증가하였다. 돼지감자의 투여는 체중 감소를 방지하고 식이효율을 높이는 효과가 있음을 시사한다.

혈청 중 AST와 ALT는 간세포에 다량 존재하는 효소로서 간세포 손상 시에 혈중으로 유출되기 때문에 간세포 손상의 지표로 이용된 다(Bursch과 Schulte-Hermann, 1986; Lee 등, 2013; Park 등, 2015). 본 연구에서 AST 및 ALT 농도는 당뇨대조군에 비해 당뇨돼 지감자군에서 유의한 감소를 나타내었다. 돼지감자 추출물은 STZ 에 의해 증가된 AST 및 ALT의 활성을 감소시켜 STZ에 의한 간손상 의 개선효과가 있음을 시사하나, 간세포의 조직학적 검사 등 추가 적 연구가 필요하다 하겠다.

당뇨로 인하여 포도당이 에너지원으로 이용되지 못하면 지방을 에너지원으로 이용하기 위해 혈중 유리지방산이 간에서 TG로 전 환되는 속도가 증가되면서 low density lipoprotein cholesterol (LDL-cholesterol) 합성증가로 이어지고(Liao 등, 2010), LDL 분 비가 촉진되는 과정에서 콜레스테롤 생합성이 증가하는 지질대사 의 이상이 초래된다(Hong 등, 2002). 돼지감자의 주 성분인 이눌린 (Inulin)은 수용성 식이섬유로써 기타 음식물과 함께 섭취 시 음식 물이 위와 장을 통과하는 시간을 지연시켜 장내의 영양소 흡수 속 도를 조절하며 간에서 지방생성효소의 활성을 낮춰준다. 결과적으 로 간의 지질 생성 물질과 VLDL (very low-density lipoprotein) 분비 능력을 감소시켜 혈중 지방 성분과 콜레스테롤의 증가를 방지 한다고 할 수 있다(Arbeeny 등, 1998; Shin 등, 2012). 본 연구에서 돼지감자의 경구 투여는 혈청 TG 및 LDL 콜레스테롤을 유의하게 감소시킴으로써 지질대사 개선에 효과가 있는 것으로 나타났다. 그 러나 실험물질로 사용한 돼지감자 추출물의 이뉼린의 성분분석과 지방대사 관련의 분자발현 연구가 계속되어야 할 것이다.

현재 인슐린 의존성 당뇨병 연구에 의하면 STZ로 유도된 당뇨쥐 에서 STZ 투여가 췌장 Langerhans 섬의 $\beta$-cell을 파괴하여 인슐린 분비가 감소되며 이로 인해 당질 대사가 비정상으로 되어 당 이용 률은 줄어드는 반면 당 신생을 촉진시켜 고혈당이 초래되는 것으로 보고되고 있다(Goldberg, 1981). 본 연구는 STZ으로 유도된 당뇨 쥐에서 식이섬유가 많은 돼지감자의 효능을 알아보기 위하여 4주 간 포도당 농도 변화를 측정한 결과 정상군에 비하여 당뇨군의 혈 
당은 3 4배 유의하게 높았으며, 당뇨 유발 후 3주 및 4주 후 당뇨대 조군에 비하여 당뇨돼지감자군은 유의한 감소를 나타내어 돼지감 자의 투여가 혈중 포도당 대사를 개선시키고 혈당 강하효과가 있는 것으로 생각된다. 이상의 실험 결과를 통해 돼지감자는 당뇨로 인 한 체중 저하를 방지하고 혈당을 강하시키며 지방대사를 개선하는 것으로 판단된다.

\section{요 약}

Streptozotocin (70 mg/kg B.W., i.p.)으로 유발된 당뇨쥐에서 돼지감자 (Helianthus tuberosus L.) 추출액의 혈당강하 및 혈중 지 질대사 개선효과를 알아보고자, SD 랫드 $(200 \sim 220 \mathrm{~g}$ ) 수컷을 3 군 $(\mathrm{NC}, \mathrm{DC}, \mathrm{DJ})$ 으로 나누어 돼지감자 추출액을 4주간 경구투여 하였 다. 본 연구 결과 음수량과 식이량은 당뇨군에서 유의한 증가를 보 였으며, 체중은 유의한 감소를 보였다 $(p<0.05)$. 그러나 당뇨돼지 감자군에서 체중감소를 줄이고 식이효율을 다소 개선하는 것으로 나타났다. 혈청 중 AST 및 ALT 농도는 당뇨대조군(DC)에 비해 당뇨 돼지감자군(DJ)은각 $14.3 \%, 27.3 \%$ 유의한감소를 보였다 $(p<0.05)$. 혈청 $\mathrm{HDL}-\mathrm{C}$ 의 농도는 $\mathrm{DC}$ 군에 비해 $\mathrm{DJ}$ 군은 $31.8 \%$ 유의한 증가를 보였다 $(p<0.05)$. 혈청 TG, LDL-C 및 glucose 농도는 DC군에 비 해 $\mathrm{DJ}$ 군에서 각 $25.4 \%, 56.6 \%$ 및 $33.0 \%$ 유의한 감소를 나타내었다 $(p<0.05)$. 혈중 포도당 농도를 측정한 결과 당뇨 유발 후 3 주 및 4 주 후 $\mathrm{DC}$ 군에 비해 $\mathrm{DJ}$ 군은 각 $31.0 \%, 31.6 \%$ 유의하게 감소를 보였 다 $(p<0.05)$. 이로서 돼지감자는 당뇨로 인한 체중 저하를 방지하 고 혈당을 강하시키며 지방대사를 개선하는 것으로 판단된다.

\section{Acknowledgements: None \\ Funding: None \\ Conflict of interest: None}

\section{References}

1. Arbeeny CA, Meysers DS, Bergquist KE, Gregg RE. Inhibition of fatty acid synthesis decrease very-low density lipoprotein secretion in the hamster. J Lipid Res. 1992,33:843-851.

2. Bach V, Kidmose U, Bj ø rn GK, Edelenbos M. Effects of harvest time and variety on sensory quality and chemical composition of Jerusalem artichoke (Helianthus tuberosus) tubers. J Food Chem. 2012,133:82-89.

3. Baltacioglu C, Esin A. Chips production from Jerusalem artichoke (Helianthus tuberosus L). Food Nutr Sci. 2012,3:13211328.

4. Bursch W, Schulte-Hermann R. Cytoprotective effect of the prostacyclin derivative iloprost against liver cell death induced by the hepatotoxins carbon tetracholoride and brombenzen.
Klin Wochenschr. 1986,7:47-50.

5. Choi PB. Effect of long-term regular exercise and drug therapy on diabetes indicators, lipid profiles, and bone mineral density in patients with type II diabetes mellitus. Korean J Phys Edu. 2011,50:513-522.

6. Connelly K, Kelly D, Gilbert R. Clinically relevant models of diabetic cardiac complications. Circ Res. 2007,101(6):78-80.

7. Dunn JS, McLetchie NGB. Experimental alloxan diabetes in the rat. The Lancet. 1943,242:384-387.

8. Goldberg RB. Lipid disorders in diabetes. Diabetes Care. 1981, 4:561-572.

9. Hong JH, Park MR, Rhee SJ. Effects of YK-209 mulberry leaves on HMG-CoA reductase and lipid composition of liver on streptozotocin-induced diabetic rats. J Korean Soc Food SCi Nutr. 2002,31(5):826-833.

10. Jekal SJ, Lee KS, Chung OB, Lee JH. Effects of electrical stimulation on wound healing and skin mast cells in streptozotocin-induced diabetic rats. Korean J Clin Lab Sci. 2008,40(2): 118-128.

11. Kim HN, Yu SY, Yoon WB, Jang SM, Jang YJ, Lee OH. Analysis of nutritional components and physicochemical properties of hot-air dried Jerusalem artichoke (Helianthus tuberosus L.) Powder. Korean J Food Sci Technol. 2014,46:73-78.

12. Kim JL, Bae CR, Cha YS. Helianthus tuberosus extract has antidiabetes effects in HIT-T15 cells. J Korean Soc Food Sci Nutr. 2010,39:31-35.

13. Kleessen B, Schwarz S, Boehm A, Fuhrmann H, Richter A, Henle $\mathrm{T}$, et al. Jerusalem artichoke and chicory inulin in bakery products affect faecal microbiota of healthy volunteers. BrJ Nutr. 2007,98:540-549.

14. Korean Diabetes Association, Korea Centers for Disease Control and Prevention. Diabetes fact sheet in Korea 2012. Korea. 2012, p2. Korean Diabetes Association, Korea Centers for Disease Control and Prevention, Korea.

15. Lee JH, Hyun SH, Park KT, Ahn TH, Kim IS. Correlation of chronic hepatitis B virus infection with diabetes mellitus indicators. Korean J Clin Lab Sci. 2013,45(1):9-15.

16. Lee JH, Jun IN. The change of tissue lipid levels and fatty acid compositions by alloxan-induced diabetes in rats. J Korean Soc Food Sci Nutr. 2004, 33:1273-1278.

17. Liao Z, Chen X, Wu M. Antidiabetic effect of flavones from Cirsium japonicum DC in diabetic rats. Arch Pharm Res. 2010,33(3):353-362.

18. Ministry of Health and Welfare. Korea Health Statistics 2010: Korea National Health and Nutrition Examination Surveys (KNHANES V-1). 2010. Ministry of Health and Welfare, Korea.

19. Park CJ, Han JS. Hypoglycemic effect of Jicama (Pachyrhizus erosus) extract on streptozotocin-induced diabetic mice. Prev Nutr Food Sci. 2015,20(2):88-93.

20. Park SY, Pak SJ, Kang SJ, Kim NY, Kim DS, Kim MJ, et al. Effects of the C3G/D3G anthocyanins-rich black soybean testa extracts on improvement of lipid profiles in STZ-induced diabetic rats. J Nutr Health. 2015,48(4):299-309.

21. Roberfroid MB. What is beneficial for health? The concept of functional food. Food Chem Toxicol. 1999,37:1039-1041.

22. Shin SH, Kwon SJ, Jo HJ, Go DH, Han JJ. Extraction and analysis of inulin from Jerusalem Artichoke. Food science and industry. 
2012,45:50-58.

23. Treayway JL, Mendys P, Hoover Dj. Glycogen phosphorylase inhibitors for the treatment of type 2 diabetes mellitus. Expert Opin Investig Drugs. 2001,10:439-454.

24. West KM, Ahuja MS, Bennett PH. The role of circulating glucose and triglyceride concentrations and their interaction with other "risk factors" as determinants of arterial disease in nine diabetic population samples from the WHO multi-national study. Diabetes Care. 1983,6:361-369.

25. Yoon JA, Son YS. Effects of fruits and stems of Opuntia ficus-indica on blood glucose and lipid metabolism in streptozotocin-induced diabetic rats. J Korean Soc Food Sci Nutr. 2009, 38(2):146-153. 